\title{
Optimization the Ratio of Palm Fatty Acid Distillate (PFAD) and Mixed Metal Soap (Al-Ca) in the Manufacture of Biodegradable Solid Lubricants
}

\author{
Sukmawati ${ }^{*}$ and Pratiwi Putri Lestari \\ Department of Chemical Engineering, Institut Teknologi Medan, Indonesia
}

\author{
DOI: $10.36348 /$ SIJCMS.2019.v02i06.003 \\ | Received: 21.09.2019| Accepted: $28.09 .2019 \mid$ Published: 30.10 .2019
}

*Corresponding author: Sukmawati

\section{Abstract}

Increased development in the industrial and transportation sectors today significantly increases the use of lubricants. This means that a significant amount of lubrication is needed to meet consumption needs in the industrial and transportation sectors. Palm Fatty Acid Destillate (PFAD) has a high enough potential to be used as a raw material for making oleochemical products, one of which is solid lubricant. This is caused by the composition of fatty acids contained in PFAD not much different from the composition of fatty acids found in palm oil. This study aims to determine the formulation of solid lubricants (grease) from PFAD and mixture metal soap (Al-Ca) as thickener which has characteristics close to SNI solid lubricants and know the quality of solid lubricants produced. The method used in the manufacture of solid grease (grease) consists of two stages. The first stage is the process of making mixed metal soap (Al-Ca) by mixing PFAD and $\mathrm{Al}(\mathrm{OH})_{3}-\mathrm{Ca}(\mathrm{OH})_{2}$ and analyzing the mixed metal soap. The second stage is the manufacture of solid lubricants (grease) from mixed metal soap (Al-Ca) and PFAD as well as analyzing the resulting product. Based on the research that has been done, the optimum solid lubricant obtained according to SNI standards is in the composition of $\mathrm{A} 1 \mathrm{~B} 1, \mathrm{~A} 1$ is the ratio of $\mathrm{Al}(\mathrm{OH})_{3}: \mathrm{Ca}(\mathrm{OH})_{2}=90 \%: 10 \%$ and $\mathrm{B} 1$ is the ratio of metal soap: $\mathrm{PFAD}=$ $10 \%: 90 \%$, so the density is $0.95 \mathrm{gr} / \mathrm{ml}$ and the penetration value is $194\left(25^{\circ} \mathrm{C}\right)$, the melting point is $97^{\circ} \mathrm{C}$ and NLGI 4 .

Keywords: Mixed metal soap, solid grease, base oil, NLGI.

Copyright @ 2019: This is an open-access article distributed under the terms of the Creative Commons Attribution license which permits unrestricted use, distribution, and reproduction in any medium for non-commercial use (NonCommercial, or CC-BY-NC) provided the original author and source are credited.

\section{INTRODUCTION}

Lubricant is a fluid that functions to protect several engine components that work, so that the lubricant can have a positive effect on the tools and machines, which can prevent wear due to friction between the components with the other components.

Today's increasing development in the industrial and transportation sectors significantly increases the use of lubricants. This means there is a considerable amount of lubrication needed to meet consumption needs in the industrial and transportation sectors.

Generally lubricants that are often found in the market are made from petroleum or petroleum base oil. With the depletion of petroleum reserves, the basic raw material for making lubricating oil is less, which can meet the needs of Indonesia. This is predicted to lead to scarcity of lubricants in the market or the increasingly expensive lubricants due to imports from abroad.
This condition certainly provides inspiration for several countries including Indonesia to continue to increase efforts to find alternative raw materials that can substitute petroleum. Vegetable oil is one of the raw materials that can be used as a base for making alternative lubricants for machines. Palm oil derivative compounds, especially glycerol and oleic acid have the potential to be developed as raw materials for synthetic lubricants. In addition, lubricating oils can also be synthesized from fatty acid esters derived from vegetable oils. Generally lubricating oil is synthesized from fatty acid esters with carbon chains in the range above, so that it has the opportunity to be developed as a raw material for lubricating oil [1].

Palm oil derivative products namely Palm Fatty Acid Destilate (PFAD) are by-products of cooking oil factories, where their utilization is still limited. In addition, PFAD is only used as a raw material for making soap with low quality [2]. 
Meanwhile, PFAD has high potential to be used as raw material for making oleochemical products, one of which is solid lubricant. This is caused by the composition of fatty acids contained in PFAD not much different from the composition of fatty acids found in palm oil. The utilization of cooking oil by-products in the manufacture of solid lubricants is carried out with a treatment technique that is the mixing of mixed metal soap (Na-Ca) with palm oil and its derivative namely PFAD which is used as a base oil. The characteristics of PFAD are influenced by three basic parameters namely boiling point, specific heat, and latent heat from fatty acids [3]. The solid lubricant is a solid or semi-solid mixture of lubricants with thickener which serves to reduce friction between two surfaces that intersect or rub against each other [4].

Additives are an additional ingredient that functions as a vitamin for solid lubricants whose uses include, as an anti-corrosion, as anti-wear, as an antioxidant, maintaining a thick lubricant viscosity (viscosity index improver). The solid lubricant is composed of several components [5], namely, basic oil (base oil), thickener, additives. According to the latest theory, base thickener and oil always exist together on the surface of the friction and do not justify popular theories that view thickener only as a sponge that releases base oil to the friction surface [6].

Based on previous research, the research team has made a solid grease from Palm Fatty Acid Distillate (PFAD) using $\mathrm{Na}$ and Li metal soap. The optimum ratio obtained in the composition of 95:5 for $\mathrm{Na}$ metal and 35:65 for Li metal [7], but the test results are still not optimal enough if applied to vehicles or machinery. And in [10] the researchers continued the study by using a mixture of $\mathrm{Li}-\mathrm{Ca}$ metal soap to obtain the optimum A2:B3 composition. A2 is a $\mathrm{LiOH}: \mathrm{Ca}(\mathrm{OH})_{2}$ ratio of $80 \%: 20 \%$ and $\mathrm{B} 3$ which is a metal soap: PFAD ratio of $70 \%: 30 \%$, a density of $0.953 \mathrm{gr} / \mathrm{ml}$, a dropping point of $105^{\circ} \mathrm{C}$, with a NLGI consistency value 6 .

In Sukmawati [8], further research was carried out using a mixture of $\mathrm{Na}-\mathrm{Ca}$ metal soap as a thickener with an optimum ratio obtained at the ratio A2: B1, A2 is the ratio of $\mathrm{NaOH}: \mathrm{Ca}(\mathrm{OH})_{2}=80 \%: 20 \%$ and $\mathrm{B} 1$ is the ratio of metal soap: PFAD $=90 \%: 10 \%$, a density of $1.108 \mathrm{gr} / \mathrm{ml}$, penetration 92, dropping point $110^{\circ} \mathrm{C}$ and consistency value of NLGI 6 were obtained.

\section{METHODOLOGY \\ Experimental Design}

The research design carried out was the process of making mixed metal soap and the process of making solid lubricants which were divided into two stages, the first year and the second year that based from the results of previous studies.

The research data collection technique that will be taken is the determination of free base content and the ingredients not soaped on metal soap. As for the solid lubricant the data obtained are density, penetration, NLGI and melting points.

\section{Variables and Process Conditions}

Raw material used: Palm Fatty Acid Destilate (PFAD), Metals used:Al and Ca, Process Variables; Fixed Variable : Stirring Temperature: $120^{\circ} \mathrm{C}$, Heating temperature PFAD: $70^{\circ} \mathrm{C}$, Solid lubricating time: 4 hours, Stirring speed: $650 \mathrm{rpm}$, Total volume of additives (Stearic, Glycerin, Phenol): $15 \mathrm{ml}$;

Change variables: Variation in Aluminum ratio: Calcium are 90: 10 (A1), 80: 20 (A2); variation in PFAD ratio:Metal soap are 10: 90 (B1), 20: 80 (B2), Analysis carried out on metal soap and solid lubricants produced; Mixed metal soap: Determination of free base content and Material is not soapy, Solid lubricant: Density, titrant, melting point, NLGI.

\section{MATERIAL}

Palm Fatty Acid Destilate (PFAD) as a material for making metal soap and raw material for making solid lubricants, mixed metals ( $\mathrm{Al}$ and $\mathrm{Ca}$ ) as a thickening agent in the manufacture of metal soap, glycerol as a substance to maintain the thickness of a solid lubricant, phenol as an anti-oxidant, and as anticorrosion stearate.

\section{METHODS}

Manufacture of Mixed Metal Soap are preparing tools and materials for making metal soap, heating PFAD as much as 100 gr to a temperature of $70^{\circ} \mathrm{C}$, stirring continuously at a speed of $650 \mathrm{rpm}$ for 30 minutes, adding $4 \mathrm{~N}$ Al-Ca $4 \mathrm{~N}$ mixed metal solution little by little while continuing to stir in accordance with variations in the manufacture of metal soap.

Free Base Content Analysis are Insert $5 \mathrm{~g}$ sample into the Erlenmeyer, adding $100 \mathrm{ml}$ of $95 \%$ alcohol and heat for 30 minutes, then cooled, Titrate with $0.5 \mathrm{~N} \mathrm{HCl}$ and phenolphtalein indicator of 2-3 drops. Content Analysis of Non-Soap are Insert $50 \mathrm{ml}$ of $0.5 \mathrm{~N}$ alcoholic $\mathrm{KOH}$ into the free base analysis solution, Heated for 1 hour then cool, Titrate with $0.5 \mathrm{~N}$ $\mathrm{HCl}$ and phenol phtalein indicator 2-3 drops, then do the same thing with the blank.

Manufacture of solid lubricants are Inserting the PFAD into the reactor then heating it to $70^{\circ} \mathrm{C}$, adding metal soap as thickener according to the predetermined variations, adding additives, Stirring with a stirring speed of $650 \mathrm{rpm}$, temperature of $120{ }^{\circ} \mathrm{C}$ and stirring time for 240 minutes, Obtain solid lubricants and analyze solid lubricants, analyzing solid lubricants with analysis parameters, namely:

Density, Penetration (ASTM D217), Melting Point (ASTM D566), NLGI (ASTM D217), Conducted 
at the LEMIGAS Oil and Gas Technology Research and Development Laboratory Center in South Jakarta

Solid Lubricant Density Analysis Procedure
Considering the weight of a clean, dry empty piqnometer then recording the weight, enter the aquadest into it and weigh it back then record the results, calculate the density of aquadest using a formula

$$
\mu=\frac{\text { (Pycnometer weight contains aquadest }- \text { Empty pycnometer weight) }}{\text { (Pycnometer volume) }} \quad \mu=\frac{g}{\mathrm{ml}}
$$

Do it the same procedure for solid lubricants.

\section{Procedure of ASTM D-217}

The order is to determine the stiffness of a grease. The P0 or unworked and P60 or worked penetration tests followed the ASTM D-217 method for full scale. This is one of the four required tests performed on every single batch of grease at Nye prior to shipping. The penetration test begins with the grease at 25 degrees Celsius, plus or minus 1 degree Celsius, being leveled into a cup. The sample size and cone weight for this test is determined by your application needs. Using a penetrometer, it is dropped into the cup for 5 seconds, creating a hole in the grease. The technician records the depth of a millimeter of this hole. This value is known as the $\mathrm{P} 0$ or unworked penetration. The grease is then sheared (or worked) using a mechanically operated device through 60 double strokes, simulating the use of the grease. When this is completed, the technician repeats the P60 value, also known as a worked penetration. Nye technicians can also carry out P10,000 and P100,000 tests, depending on the application's specifications.
The penetration values of P60 are rated using the NLGI grade chart from 000 to 6 . These values determine the stiffness of the grease and how the grease will react over time to service and wear. The higher the penetration value, the softer the grease. The lower the penetration value, the stiffer the grease. Grease that is not too easy to pass from the area that needs to be lubricated. Grease that is too stiff may not effectively migrate to those areas that need to be lubricated.

\section{ASTM-D-566}

Fill a test cup with a sample by pressing the larger opening into the grease to be tested until the cup is filled. Place the corcks on the thermometer depth gage position in the test tube. Replace the depth gage with the grease cup. Suspend the test tube in the oil bath to a depth corresponding to the $76 \mathrm{~mm}$ immersion mark on the thermometer. Suspend the second thermometer in the oil bath so that its bulb is at approximately the same level as the bulb of the test tube thermometer. Stir the oil bath and heat. Two determination can be made simultaneously in the same bath.

\section{RESULT}

Table-1: Test Result Characteristics of Grease

\begin{tabular}{|c|c|c|c|c|c|c|}
\hline NO & $\begin{array}{c}\text { Composition (\%) } \\
\text { (PFAD : Metal soap) }\end{array}$ & $\begin{array}{c}\text { Density } \\
(\text { gr/ml) }\end{array}$ & $\begin{array}{c}\text { titrate 25 }{ }^{\mathbf{C}} \\
\text { ASTM D 217 }\end{array}$ & $\begin{array}{c}\text { Dropping Point } \\
\text { ASTM } \\
\text { D 566 }\end{array}$ & $\begin{array}{c}\text { NLGI Grade } \\
\text { ASTM D 217 }\end{array}$ & The colour \\
\hline 1 & A1 : B1 & 0,95 & 194 & 97 & 4 & Brown \\
\hline 2 & A1 : B2 & 0,91 & 140 & 83 & 5 & Brown \\
\hline 3 & A1 : B3 & 0,87 & 115 & 90 & 6 & Brown \\
\hline 4 & A2 : B1 & 0,96 & 34 & 86 & $>6$ & Brown \\
\hline 5 & A2 : B2 & 0,91 & 34 & 98 & $>6$ & Brown \\
\hline 6 & A2 : B3 & 0,87 & 50 & 89 & $>6$ & Brown \\
\hline
\end{tabular}

Description

$$
\begin{aligned}
& \mathrm{A}=\mathrm{Ratio} \mathrm{Al}(\mathrm{OH})_{3}: \mathrm{Ca}(\mathrm{OH})_{2}(\%) \\
& \mathrm{B}=\mathrm{Ratio} \mathrm{PFAD}: \text { Metal soap }(\%) \\
& \mathrm{A} 1: \mathrm{B} 1=(90: 10) ;(10: 90) \\
& \mathrm{A} 1: \mathrm{B} 2=(90: 10) ;(20: 80) \\
& \mathrm{A} 1: \mathrm{B} 3=(90: 10) ;(30: 70) \\
& \mathrm{A} 2: \mathrm{B} 1=(80: 20) ;(10: 90) \\
& \mathrm{A} 2: \mathrm{B} 2=(80: 20) ;(20: 80) \\
& \mathrm{A} 2: \mathrm{B} 3=(80: 20) ;(30: 70)
\end{aligned}
$$

\section{DISCUSSIONS} Density

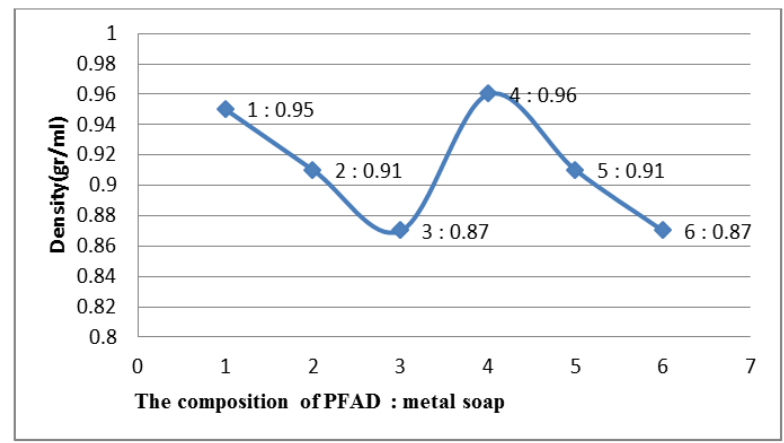

Fig-1: Graph of the composition ( \% ) vs Density (gr/ ml) 
Description

$\mathrm{A}=\mathrm{Ratio}$ of $\mathrm{NaOH}: \mathrm{Ca}(\mathrm{OH})_{2}(\%)$
$\mathrm{B}=\mathrm{Ratio}$ of metal soap $:$ Base Oil $(\%)$
$\mathrm{A} 1: \mathrm{B} 1=(90: 10) ;(90: 10)$
$\mathrm{A} 1: \mathrm{B} 2=(90: 10) ;(80: 20)$
$\mathrm{A} 1: \mathrm{B} 3=(90: 10) ;(70: 30)$
$\mathrm{A} 2: \mathrm{B} 1=(80: 20) ;(90: 10)$
$\mathrm{A} 2: \mathrm{B} 2=(80: 20) ;(80: 20)$
$\mathrm{A} 2: \mathrm{B} 3=(80: 20) ;(70: 30)$

From the figure above the graph of the relationship of composition (PFAD:Al-Ca metal soap) to density shows a decrease, both for compositions 1,2 and 3 (type of metal soap A1) and compositions 4, 5, and 6 (type of metal soap A2). Where in the composition 1 (one) (A1: B1) obtained a density of 0.95 gr / ml; composition 2 (two) (A1:B2) obtained a density of $0.91 \mathrm{gr} / \mathrm{ml}$, composition 3 (three) (A1:B3) obtained a density of $0.87 \mathrm{gr} / \mathrm{ml}$; composition 4 (four) (A2:B1) obtained a density of $0.96 \mathrm{gr} / \mathrm{ml}$; composition of 5 (five) (A2:B2) obtained a density of $0.91 \mathrm{~g} / \mathrm{ml}$; and the composition of 6 (six) (A2: B3) obtained a density of $0.87 \mathrm{gr} / \mathrm{ml}$. This is due to the decreasing composition of metal soap and increasing composition of PFAD resulting in a decrease in lubricant density. This condition is slightly different from commercial solid lubricants which is $0.82 \mathrm{gr} / \mathrm{ml}$.

The ratio of $\mathrm{Al}(\mathrm{OH})_{3}$ to $\mathrm{Ca}(\mathrm{OH})_{2}$ also affects the density of the solid lubricant. This density is influenced by the density of each metal, where $\mathrm{Al}$ $(\mathrm{OH})_{3}$ has a density of $2.4 \mathrm{gr} / \mathrm{ml}[9]$ and $\mathrm{Ca}(\mathrm{OH})_{2}$ has a density of $2.2 \mathrm{gr} / \mathrm{ml}$ [9]. This causes the density of solid lubricants with $\mathrm{A} 1$ and A2 metal soap types to have a slight difference because the densities of the two types of metals are also not much different. From the results of tests conducted, it can be said that palm oil based solid lubricants that have been formulated have the same relative density as commercial lubricants, ranging from $0.827 \mathrm{gr} / \mathrm{ml}-1,107 \mathrm{gr} / \mathrm{ml}$.

\section{The Titrant}

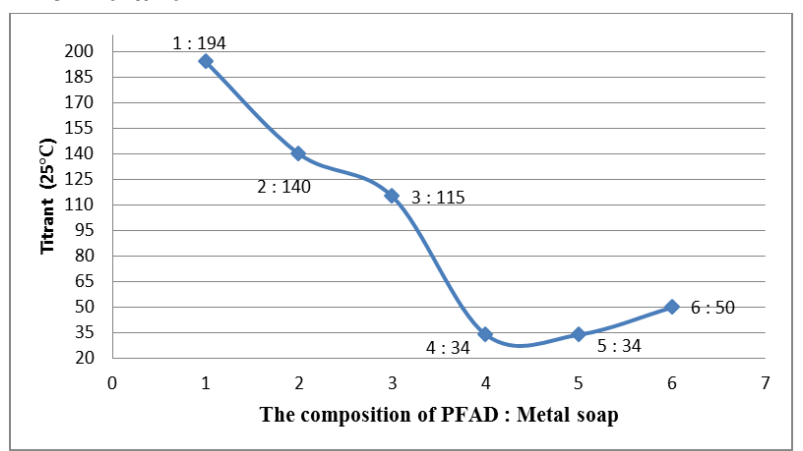

Fig-2: The graph of Composition (\%) vs Titrant $\left(25^{\circ} \mathrm{C}\right)$

From the graphic image of the relationship of composition (PFAD: Al-Ca metal soap) to the penetration value, it shows a decrease and increase the penetration value. Where in the composition of 1 (one) (A1:B1) a penetration of $194 \mathrm{~mm} / 10$ was obtained; composition 2 (two) (A1:B2) obtained a penetration of $140 \mathrm{~mm} \mathrm{/} \mathrm{10;} \mathrm{composition} \mathrm{of} 3$ (three) (A1:B3) obtained a penetration of $115 \mathrm{~mm} / 10$; composition 4 (four) (A2:B1) obtained $34 \mathrm{~mm} \mathrm{/} 10$ penetration; composition of 5 (five) (A2:B2) a penetration of $34 \mathrm{~mm}$ / 10 is obtained; and the composition of 6 (six) (A2:B3) is obtained a penetration of $50 \mathrm{~mm} / 10$. From the above data, we can see the decreasing composition of PFAD and the increasing composition of metal soap resulting in a decrease in the value of lubricant penetration. The resulting solid lubricant has an NLGI value close to the hardness level of commercial solid lubricants according to NLGI, namely NLGI 2 . Where in composition 1 , with a penetration value of $194 \mathrm{~mm} / 10$ included in NLGI 4, composition 2 with a penetration value of 140 $\mathrm{mm} / 10$ included in NLGI 5, composition 3 with a penetration value of $115 \mathrm{~mm} / 10$ included in NLGI 6 , composition 4 with penetration value $34 \mathrm{~mm} \mathrm{/} 10$ included in NLGI> 6 , composition 5 with penetration value $34 \mathrm{~mm} / 10$ included in NLGI> 6, composition 6 with penetration value $50 \mathrm{~mm} / 10$ included in NLGI> 6.

\section{The Dropping Point of Grease}

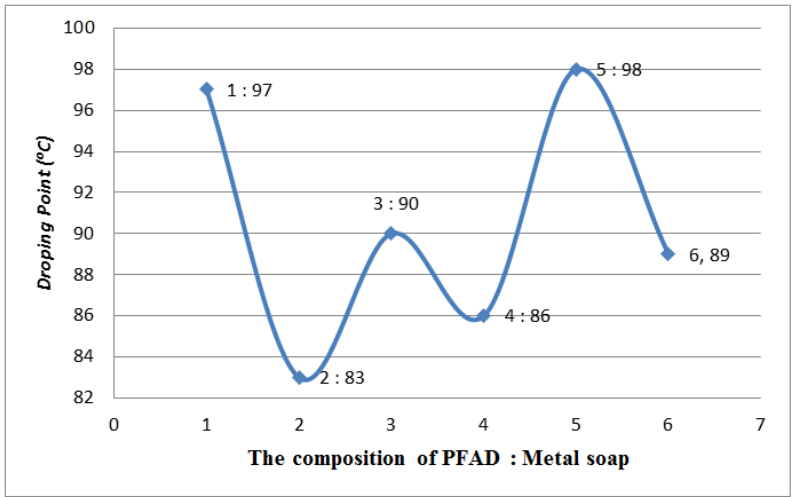

Fig-3: The graph of composition (\%) vs Dropping point $\left({ }^{\circ} \mathrm{C}\right)$

From the graphic image of the relationship of composition (PFAD:Al-Ca metal soap) to the melting point (dropping point) shows a decrease in the melting point. Wherein at composition 1 (one) (A1:B1) a melting point of $97^{0} \mathrm{C}$ is obtained, composition 2 (two) (A1: B2) a melting point of $83^{\circ} \mathrm{C}$, composition of 3 (three) (A1:B3) a melting point of $90^{\circ} \mathrm{C}$, composition 4 (four) (A2:B1) obtained at a melting point of $86^{\circ} \mathrm{C}$; composition of 5 (five) (A2:B2) a melting point of $98^{\circ} \mathrm{C}$ is obtained; and the composition of 6 (six) (A2: B3) yields a melting point of $89^{\circ} \mathrm{C}$.

Based on the research results obtained by the number of bases, which are in accordance with the quality standards set by the Ministry of Industry and Trade in accordance with SNI 06-2048-1990 about the quality standards for metal soap. From the results of the study the levels of free base obtained for the type of metal soap A1 is $0.05 \%$ and the type of metal soap A2 is $0.02 \%$ or slightly above the neutral level (point 0 ). In addition to the free base content in metal soap also analyzed the characteristics of non-soapy material 
numbers, where the A1 metal type is $0.86 \%$ and A2 metal soap $0.84 \%$ The focus of the manufacture of lubricants produced in this study is to get a solid lubricant formula that is close to the characteristics of commercial solid lubricants based on ASTM (American Society for Testing and Materials International) quality standards. In this research, the raw material used in the manufacture of solid lubricants is Palm Fatty Acid Distillate (PFAD) and metal soap. The metal soap used in the formulation of solid lubricants is obtained by safonification using aluminum (Al $(\mathrm{OH}) 3)$ and Calcium $(\mathrm{Ca}(\mathrm{OH}) 2)$ with PFAD raw material.

The raw materials consisting of base oil are PFAD and Al-Ca alloy soap after being physically blended and have become solid lubricants then their characteristics are analyzed using the methods of ASTM D-217 for penetration and ASTM D-566 for point melting conducted at the Laboratory of Research and Development Center for Oil and Gas Technology "LEMIGAS" Jalan Ciledug Raya No 109, RT.07 / RW.05, Cipulir, Kebayoran Lama, South Jakarta City, Special Capital Region of Jakarta. Density testing was conducted at the Laboratory of Research in the Chemical Engineering ITM-Medan.

From Figure-1 it can be seen that the ratio of $\mathrm{Al}(\mathrm{OH})_{3}$ to $\mathrm{Ca}(\mathrm{OH})_{2}$ also affects the density of solid lubricants. This density is influenced by the density of each metal, where $\mathrm{Al}(\mathrm{OH})_{3}$ has a density of $2.4 \mathrm{gr} / \mathrm{ml}$ [9] and $\mathrm{Ca}(\mathrm{OH})_{2}$ has a density of $2.2 \mathrm{gr} / \mathrm{ml}$ [9]. This causes the density of solid lubricants with A1 and A2 metal soap types to have a slight difference because the densities of the two types of metals are also not much different.

From Figure-2 above we can see the decreasing composition of PFAD and the increasing composition of metal soap resulting in a decrease in the value of lubricant penetration.

From Figure-3 it can be seen that the decreasing composition of the metal soap and the increasing composition of the PFAD result in a decrease in the melting point. However, each sample experienced an increase and decrease in droping points. These conditions are in accordance with the theory that the minimum limit of melting point allowed for solid lubricants is $800 \mathrm{C}$, where the higher the melting point owned by a solid lubricant, the better its resistance in maintaining the physical condition of solid lubricants, so that solid lubricants that have melting points height will not melt quickly and increase service life. These results are in accordance with the specification characteristics and performance parameters of solid lubricants for the quality level of NLGI GA, SNI 067069- 8- 2005.

\section{CONCLUSION}

Palm Fatty Acid Destilate (PFAD) can be used as a raw material for making palm oil based grease which is environmentally friendly and has the characteristics of commercial solid lubricants. The variation of the composition of the mixture of metal soap (thickening agent) and PFAD (base oil) in the manufacture of solid lubricants affects the results of density analysis, penetration, melting point and NLGI. The best solid grease produced in accordance with ASTM standards and SNI $06-7069-8$ - 2005 which is included in Grade A, is found in the ratio of metal soap to base oil, namely $\mathrm{A} 1$ : $\mathrm{B} 1$. $\mathrm{A} 1$ is the ratio of $\mathrm{Al}$ $(\mathrm{OH})_{3}: \mathrm{Ca}(\mathrm{OH})_{2}=90 \%: 10 \%$ and $\mathrm{B} 1$ which is the ratio of metal soap: $\mathrm{PFAD}=10 \%: 90 \%$ with the following criteria: Density: $0.95 \mathrm{gr} / \mathrm{ml}$, Penetration: $194\left(25^{\circ} \mathrm{C}\right)$, Melting point: $97^{\circ} \mathrm{C}$, NLGI: 4

\section{REFERENCES}

1. Garnida. (2002). Pelumas dan Pelumasan Mesin Diesel dalam situs www.Google.com

2. Darnoko, D., Siahaan, D., Eka, N., \& Elishabeth, J. (2003). Teknologi Pengolahan Kelapa Sawit dan Produk Turunannya. Pusat Penelitian Kelapa Sawit. Medan.

3. Bernandini, E. (1985). Oilseeds. Oils and Fats Volume II Oils and Fats Processing B.E. Oil. Publishing House Via L. Lilio. 19. Roma.

4. Hartono, A. J. (1991). Lekuk-Liuk-Liuk Pelumas. Penerbit Andi Offset. Yogyakarta.

5. Anonimous. (1998). Klasifikasi Grease. dalam situs www.NLGI Classification System.html.

6. Lansdown A. R. (2007). Lubrication and Lubricant Selection, A Practical Guide. Third Edition. London: Professional Engineering Publishing Limited.

7. Sukmawati. (2012). Optimasi Rasio Palm Fatty Acid Destilate( PFAD) Dan Sabun Logam Pada Pembuatan Pelumas Padat (grease) Biodegradable. ITM. Medan.

8. Sukmawati, P. P., \& Lestari, S. (2019). Optimization Ratio of Mixed Metal Soaps and Palm Fatty Acid Distillate (PFAD) on Making Grease. IOP Conference Series: Earth and Environmental Science.

9. Perry's. (1999). Chemical Handbook Technology \& Engineering. Seventh Edition. McGraw-Hil.

10. Sukmawati. (2016). Optimasi Sabun Logam Campuran (Li-Ca) Pada Pembuatan Pelumas Padat (Grease) Dari Palm Fatty Acid Destilate (PFAD). SNTK TOPI. Universitas Riau. 